\title{
Harpacticoida (Copepoda) of the northern East Sea (the Sea of Japan) and the southern Sea of Okhotsk: diversity, taxocenes, and biogeographical aspects
}

\author{
Elena S. Chertoprud ${ }^{\mathrm{a} *}$, Svetlana E. Frenkel ${ }^{\mathrm{b}}, \mathrm{Kichoon}_{\mathrm{Kim}}^{\mathrm{c}}$ and Wonchoel Lee ${ }^{\mathrm{d}}{ }^{\mathrm{d}}$ \\ ${ }^{a}$ Biological Faculty, Moscow State University, Moscow, Russia; ${ }^{b}$ Russian Federal Research \\ Institute of Fisheries and Oceanography, Moscow, Russia; ${ }^{c}$ Biodiversity Research Institute, \\ Marine Act co., Seoul, Korea; ${ }^{d}$ Department of Life Science, College of Natural Sciences, \\ Hanyang University, Seoul Korea
}

(Received 25 September 2014; accepted 11 May 2015; first published online 29 June 2015)

\begin{abstract}
Based on novel data and a literature review, an inventory of Harpacticoida from the northern part of the East Sea and the southern part of Sea of Okhotsk is compiled. A total of 151 species belonging to 70 genera and 26 families, of which 16 species are deemed to be new to science, are recognized from the region. Twelve harpacticoid species assemblages are described from marine and brackish water soft sediments and the phytal zone. Estuarine faunas were similar throughout the East Sea and Sea of Okhotsk, both in species composition and dominant-taxon structure. Conversely, the fauna of marine soft sediment and phytal zones differed greatly throughout this region. This distinction may have been caused by differences in dispersal rates or by differences in environmental conditions. The distribution of littoral and sublittoral harpacticoids was determined primarily by climatic factors and the temperature of surface waters. Three basic sub-regions were distinguished within the survey area: Korean, which includes many tropical taxa $(39 \%)$ and a smaller amount (about $20 \%$ ) of boreal taxa; Primorye, where boreal and subarctic-arctic species $(>40 \%)$ predominate, and representatives of the tropical complex are rare $(17 \%)$; and Soya, with a mix of tropical $(22 \%)$ and boreal $(31 \%)$ faunal elements. The faunas of the Korean and the Primorye sub-regions are distinct, whereas that of the Soya has intermediate features.
\end{abstract}

Keywords: Harpacticoida; species richness; taxocenes; biogeographical sub-region

\section{Introduction}

The marine meiofauna of the Russian Far East has not been investigated in detail, with research effort in the region having focused on studies of highly abundant and diverse nematode fauna (e.g. Pavluk and Belogurov 1979; Fadeeva and Belogurov 1984; Pavluk 1984; Fadeeva 1991; Smirnova 2012). Copepods of the order Harpacticoida, the second-most abundant meiobenthic taxon, and one that plays a key role in trophic chains, have not been subject to any comparable degree of research effort (Chertoprud 2013).

Harpacticoids are basic microalgal consumers (Carman et al. 1997). They also serve as prey for many organisms, including commercially important salmonids (Chupachin and Kaev 1980; Kaev et al. 1993; Trofimov 1999; Ivankov et al. 1999; Kaev 2003). Thus far, 144 species have been reported from the Russian Far East

\footnotetext{
*Corresponding author. Email: horsax@yandex.ru
} 
(East Sea, Sea of Okhotsk, and Bering Sea) (Chertoprud 2013). To place this tally in perspective, the White and Black Seas, more than 10 times smaller in area, are reported to have 278 and 228 species respectively (Chertoprud et al. 2010).

The harpacticoid fauna of the Russian Far East is very diverse and includes many undescribed species (this has been confirmed by Korean and Japanese studies in the southern part of the East Sea; Itô 1979, 1981; Back and Lee 2012, 2013). For the Russian part of the East Sea, benthic copepods have been described from the estuary of the Razdol'naya River (Primorye) (Borutzky 1929), the Posyet Bay (Chislenko 1971, 1978), and Paramushir Island (Chislenko 1980); the harpacticoid fauna of the southern part of the Sea of Okhotsk had not been investigated. Details of harpacticoid taxocenes are not available for the entire region, and those data that do exist are limited or localized to descriptions of complexes from estuaries and lagoons in the Bering Sea, the Sea of Okhotsk, and the East Sea (Ivankov et al. 1999; Smirnova 2012; Chertoprud et al. 2014; Zavarsin and Atamanova 2014).

Various biogeographic appraisals of the Sea of Okhotsk and the East Sea have been proposed in which up to 10 biogeographical sub-regions have been recognized (e.g. benthic macrofauna: Gur'ianova 1964; Zezina 1976; Golikov et al. 2001; fishes: Kafanov et al. 2000; zooplankton: Kuhn 1975). None of these reviews has incorporated harpacticoids or taken other meiofaunal taxa into consideration.

The goals of this study were: to describe harpacticoid diversity and species composition based on original data and published sources; to describe the main types of marine and brackish-water taxocenes based on original data; and to examine these data for any latitudinal trends in species composition.

\section{Materials and methods \\ Sampling}

All samples were collected from four regions in Russia: Khabarovsk district (estuary of the Tumnin River); Primorye (Petrov Island, Bays: Amur, Vostok, St. Vladimir, Kievka and Pestchanay); Sakhalin Island (salt lakes and lagoons Tunaycha, Ismenchivoe, Ptichie); and South Kuril Islands (Kunashir and Iturup (Prostor Bay)) (Figure 1).

More than 240 qualitative and quantitative samples from littoral, sublittoral, phytal, and coastal zones and coastal water masses from 72 marine stations were analysed. Samples were collected between 2009 and 2014. Stomach contents of salmon fry (Oncorhynchus keta and O. gorbuscha) were investigated to determine the significance of harpacticoids in their diet.

Samples for quantitative analysis were collected from bottom sediments using a $1.5 \mathrm{~cm}$ diameter corer (surface area, $1.77 \mathrm{~cm}^{2}$ ). Three replicate sediment samples were taken from stations in the littoral and upper sublittoral zone (during low tide at a depth of $50 \mathrm{~cm}$ ). Only the upper $5 \mathrm{~cm}$ of sediment was retrieved. Granulometric analyses were performed on sediments collected from all stations. Mean grain size, and the silt $(<0.63 \mathrm{~mm})$, and large-sized fragment $(\geq 2 \mathrm{~mm})$ content were determined.

Samples for quantitative analysis from the coastal water mass were obtained by vertical haul from the bottom to surface by Juday net with $76 \mu \mathrm{m}$ mesh cone. Harpacticoids were collected from coastal macrophytes (brown, red, and green algae and higher plants such as Zostera sp.) by washing with $2 \%$ formalin solution. 




Figure 1. Map of the examined parts of the Pacific region including the main annual surface water isotherms (Japan Meteorological Agency 1991). Original data: •approximate locations of the water areas investigated; data from the literature: *numbers of stars indicate the level of knowledge of the area.

Salmon fry stomach contents were investigated in two steps: preparation of the fish stomach, then differentiation of food objects. All samples were fixed in $4 \%$ formalin solution.

\section{Literature data}

Published data on harpacticoids from throughout the East Sea and southern part of the Sea of Okhotsk were used to prepare an inventory of taxa from the region (see Supplement). Faunal data were available for a number of Russian waters (coastal waters of Primorye, Khabarovsk region, Sakhalin Island, and Kuril Islands), Japanese islands, and the southern and eastern coastal regions of South Korea (Figure 1). The most thoroughly investigated region was the Korean Peninsula, for which 57 articles were available. The Japanese island fauna is described in 19 papers, with a detailed analysis of the harpacticoid fauna of Hokkaido Island carried out in five articles. Nine publications report the fauna of the Russian sector of the East Sea. The fauna of the Sea of Okhotsk is described in five published accounts. 
The world-wide database on shallow-water harpacticoids (Chertoprud et al. 2010; Azovsky et al. 2012) was used to compare the faunas of the Okhotsk and East Seas with those of other regions (South China, Yellow and Bering Seas), in addition to analysing species distribution ranges.

\section{Taxonomy and life forms}

The taxonomy followed the European Register of Marine Species (Costello et al. 2001). Adult harpacticoids were identified using Boxshall and Halsey (2004), Wells (2007), Lang (1948, 1965), and Itô (1968, 1969, 1970, 1972, 1974, 1976, 1979, 1981). The taxonomic status of Miraciidae followed Willen (2002). Nomenclature within families and genera and recognition of synonymous species followed Bodin (1997) and Huys (2009). Species not present in the aforementioned lists were assigned to genera following Lang (1948) and Pesce (2007).

Harpacticoid species were allocated to life forms following Chertoprud et al. (2006), with phytal, planktonic, epibenthic, facultative interstitial (represented by small non-specialized species), and obligate interstitial (with vermiform and lanceolate habitus) forms recognized.

\section{Distribution range typology}

We used a number of formal criteria to describe the distribution ranges of species. Cosmopolitan species were those that occurred in at least three oceans, in addition to having a tropical-subarctic/arctic distribution. A similar criterion was used to characterize cosmopolitan species as defined by Finlay and Fenchel (2004). Endemic taxa were those we considered to have restricted or local distributions within an investigated region, though further investigation may reveal these to have wider distributions; accordingly the appropriate term 'provisional endemic' is used. 'Subtropical' and 'subarctic' groups included those species that occurred only in tropical-subtropical and Arctic-Subarctic zones, respectively. Species inhabiting the temperate climatic zone were considered 'boreal.'

\section{Statistical analysis}

\section{Taxocene definition and structural comparison}

The Braun-Blanquet method was used to classify and describe harpacticoid species complexes. This approach is widely applied in plant ecology (Mirkin et al. 2001) and has been modified recently for use with coastal meiobenthos (Chertoprud et al. 2006). This method allows differentiation of assemblages (taxocenes) of species in a series of samples, based on groups of dominant, specific, and discriminating species.

Pairwise similarity of the species composition was evaluated in samples using the Czekanowski index (D) (Magurran 2004):

$$
D(x, y)=\sum_{i=1} \sin \left(X_{i}, Y_{i}\right)
$$

where $X_{i}, Y_{i}$ are the proportion of individuals belonging to the $i$ th species of all individuals found in samples $X$ and $Y$, respectively. 
This index depends on abundance changes of dominant and rare species and is used for quantitative data analysis and to count portions, calculated based on species abundance.

\section{Comparing regional faunas}

To compare composition of regional faunas, we calculated the percentage taxonomic overlap between regions, and the proportion of endemic species compared with that of cosmopolitan species. Similarity in faunal composition between regions was estimated using the Kulczynski index $(K)$ for qualitative data (Urbakh 1975):

$$
\mathcal{K}(x, y)=(a /(a+b)+a /(a+c)) / 2,
$$

where $a$ is the number of common species in fauna groups $x$ and $y$; and $b$ and $c$ are the numbers of species restricted to one of the groups. This index is not sensitive to negative coincidences, which is convenient for estimating the similarity between faunas from different regions when individual lists under comparison contain only limited parts of the total species set. This index is used often for biogeographic analyses of Recent faunas (Murray et al. 2002; Azeria 2004).

We applied the multi-dimensional scaling method PRIMER (version 6) for graphical representation of similarity in species composition between regions (Clarke and Gorley 2001). This method allows for a comparison of objects on a plane so that all distances between points correspond to a certain value. Consequently, this approach helps to visualize the cluster structure of selected stations.

\section{Results \\ Species richness and composition of harpacticoid faunas}

East Sea

All data sources identify 88 species distributed amongst 60 genera, and 24 families of Harpacticoida in this region. Before our study only 23 species had been reported from it (Chertoprud 2013). The composition of each family and the genus and species diversity are shown in Table 1. Eight of these species were considered to be new to science: Halectinosoma sp. n. 1, 2, and 3; Pseudonychocamptus sp. n. 1, Paramesochra sp. n. 1, Emertonia sp. n. 1, Parastenhelia sp. n. 1 and Tisbe sp. n. 1. Four species from the Primorye region were identified to the genus level because only one sex was found. Overall, the richest families were Miraciidae (11 species) and Ectinosomatidae (10 species). The species:genus ratio was low (1.46).

Epibenthic harpacticoids (inhabiting silt deposits and the surface of soft sediments) dominated the fauna and comprised half of all species (Table 2). The diversity of phytal fauna was high. Obligate interstitial Harpacticoida had the lowest species richness, and were represented by families Darcythompsoniidae, Ectinosomatidae, Cylindropsyllidae, Leptastacidae, and Paramesochridae. The number of facultative interstitial species was not much higher. Only one species, Microsetella norvegica, was considered planktonic.

Provisional endemics constituted almost one third of the fauna (Table 2). Species inhabiting cold waters in boreal, subarctic, and arctic areas comprised 
Table 1. List of harpacticoid families with the number of genera and species in each family from the northern part of the East Sea and the southern part of the Sea of Okhotsk.

\begin{tabular}{|c|c|c|c|c|}
\hline \multirow[t]{2}{*}{ Family } & \multicolumn{2}{|c|}{ Northern part of the East Sea } & \multicolumn{2}{|c|}{$\begin{array}{c}\text { Southern part of the Sea of } \\
\text { Okhotsk }\end{array}$} \\
\hline & $\begin{array}{l}\text { Number of } \\
\text { genera }\end{array}$ & $\begin{array}{l}\text { Number of } \\
\text { species }\end{array}$ & $\begin{array}{l}\text { Number of } \\
\text { genera }\end{array}$ & $\begin{array}{l}\text { Number of } \\
\text { species }\end{array}$ \\
\hline Ameiridae & 2 & 4 & 5 & 11 \\
\hline Arenopontiidae & 1 & 1 & 1 & 1 \\
\hline Canthocamptidae & 3 & 6 & 3 & 5 \\
\hline Canuellidae & 1 & 1 & - & - \\
\hline Cletodidae & 3 & 3 & 2 & 2 \\
\hline Cylindropsyllidae & 1 & 1 & - & - \\
\hline Dactylopusiidae & 3 & 4 & 2 & 7 \\
\hline Darcythompsoniidae & 1 & 1 & 1 & 1 \\
\hline Ectinosomatidae & 5 & 10 & 4 & 10 \\
\hline Hamondiidae & - & - & 1 & 1 \\
\hline Harpacticidae & 3 & 8 & 3 & 9 \\
\hline Laophontidae & 6 & 8 & 5 & 8 \\
\hline Leptastacidae & 2 & 2 & 2 & 3 \\
\hline Longipediidae & 1 & 1 & - & - \\
\hline Miraciidae & 9 & 11 & 8 & 15 \\
\hline Nannopodidae & 2 & 2 & 1 & 1 \\
\hline Paramesochridae & 3 & 4 & 2 & 2 \\
\hline Parastenheliidae & 1 & 1 & 1 & 2 \\
\hline Peltidiidae & 1 & 1 & 1 & 1 \\
\hline Pseudotachidiidae & 1 & 1 & 2 & 2 \\
\hline Rhynchothalestridae & 1 & 2 & - & - \\
\hline Tachidiidae & 4 & 4 & 2 & 2 \\
\hline Tegastidae & 1 & 1 & 1 & 1 \\
\hline Tetragonicipitidae & - & - & 1 & 1 \\
\hline Thalestridae & 3 & 4 & 4 & 10 \\
\hline Tisbidae & 2 & 7 & 2 & 9 \\
\hline Total & 60 & 88 & 54 & 104 \\
\hline
\end{tabular}

$42 \%$ of total diversity. Species specific to tropical and subtropical latitudes were relatively rare.

\section{Sea of Okhotsk}

The inventory of harpacticoids from the southern part of the Sea of Okhotsk comprised 104 species distributed in 54 genera and 22 families of Harpacticoida (Table 1). Before the present study only 16 species were reported from this region (Chertoprud 2013). Eleven of these species are considered to be new to science: Mesochra sp. n. 1, Cletodes sp. n. 1, Dactylopusia sp. n. 1, Halectinosoma sp. n. 1, 2 and 3; Paraleptastacus sp. n. 1, Amphiascoides sp. n. 1, Schizopera sp. n. 1, Wellsopsyllus sp. n. 1 and Amenophia sp. n. 1. The most species-rich families were Miraciidae (15 species) and Ameiridae (11 species). The species:genus ratio was higher than that of the East Sea (1.92). 
Table 2. Characteristics of the life forms and distribution ranges in the Harpacticoida faunas from the northern part of the East Sea and the southern part of the Sea of Okhotsk.

\begin{tabular}{|c|c|c|c|c|c|}
\hline \multicolumn{6}{|c|}{ Number of species according to life form ( $\%$ of the total fauna) } \\
\hline Regions & Epibenthic & Phytal & $\begin{array}{l}\text { Obligate } \\
\text { interstitial }\end{array}$ & $\begin{array}{c}\text { Facultative } \\
\text { interstitial }\end{array}$ & Planktonic \\
\hline $\begin{array}{l}\text { Northern part of } \\
\text { the East Sea }\end{array}$ & $44(50 \%)$ & $22(25 \%)$ & $9(10 \%)$ & $12(14 \%)$ & $1(1 \%)$ \\
\hline $\begin{array}{l}\text { Southern part of the } \\
\text { Sea of Okhotsk }\end{array}$ & $37(36 \%)$ & $33(32 \%)$ & $9(9 \%)$ & $23(22 \%)$ & $2(2 \%)$ \\
\hline \multicolumn{6}{|c|}{ Number of species with different areas ( $\%$ of the total fauna) } \\
\hline Regions & $\begin{array}{c}\text { Provisional } \\
\text { endemics }\end{array}$ & Cosmopolitan & $\begin{array}{c}\text { Subarctic and } \\
\text { Arctic }\end{array}$ & Boreal & $\begin{array}{r}\text { Subtropical } \\
\text { and Tropical }\end{array}$ \\
\hline $\begin{array}{l}\text { Northern part of } \\
\text { the East Sea }\end{array}$ & $27(31 \%)$ & $9(10 \%)$ & $16(18 \%)$ & $21(24 \%)$ & $15(17 \%)$ \\
\hline $\begin{array}{l}\text { Southern part of the } \\
\text { Sea of Okhotsk }\end{array}$ & $28(27 \%)$ & $13(13 \%)$ & $11(11 \%)$ & $33(32 \%)$ & $19(18 \%)$ \\
\hline
\end{tabular}

The numbers of epibenthic and phytal species were similar (Table 2). There were few obligate interstitial Harpacticoida, represented by families Darcythompsoniidae, Ectinosomatidae, Leptastacidae and Paramesochridae. The number of facultative interstitial forms was greater. There were only two planktonic harpacticoids, both of which were species of Microsetella.

Boreal species accounted for one third of the fauna, and the diversity of provisional endemics was slightly lower (Table 2). Typically warm-water species accounted for $<20 \%$ of all taxa; subarctic and arctic species were rare.

\section{The taxocenes structure}

Using the modified Braun-Blanquet method 12 harpacticoid taxocenes were apparent in the northern part of the East Sea and southern part of Sea of Okhotsk. The characteristics of the four most widely distributed taxocenes are presented in Table 3. Below we describe the harpacticoid taxocenes found in different habitats.

\section{A. Marine soft sediments: littoral and upper sublittoral zones}

Six taxocene types were revealed: three characteristic of silty sand with detritus, and three of washed sand.

Taxocene no. 1 was most widely distributed and associated with silty sands with detritus. The dominant species were Parastenhelia sp. n. 1 and Halectinosoma sp. n. 3, comprising $50-80 \%$ of the abundance (Table 3). This taxocene is typical of Kunashir and Sakhalin Islands as well as the Primorye region. The similarity of the stations from different loci was medium $(\mathrm{D}=0.48 \pm 0.07)$. Other taxocenes were rarer. The second taxocene occurred in the Primorye region. Paramphiascella was dominant in 


\section{E.S. Chertoprud et al.}

Table 3. Characteristics of widely distributed harpacticoid taxocenes in marine sublittoral and phytal zones, estuaries, and brackish-water lagoons in the East Sea and the southern part of the Sea of Okhotsk. Relative species abundances in the different taxocenes are presented.

\begin{tabular}{|c|c|c|c|c|}
\hline Taxocene number & 1 & 2 & 3 & 4 \\
\hline Biotope & Upper sublittoral & $\begin{array}{l}\text { Estuary, brackish } \\
\text { lagoons }\end{array}$ & $\begin{array}{l}\text { Estuary, brackish } \\
\text { lagoons }\end{array}$ & Phytal zone \\
\hline Number of stations & 16 & 11 & 8 & 5 \\
\hline Regions & $\begin{array}{l}\text { Primorye, } \\
\text { Sakchalin } \\
\text { and Kunashir } \\
\text { Islands }\end{array}$ & $\begin{array}{l}\text { Primorye and } \\
\text { Sakchalin } \\
\text { Island }\end{array}$ & $\begin{array}{l}\text { Primorye, } \\
\text { Kunashir } \\
\text { and Iturup } \\
\text { Islands }\end{array}$ & $\begin{array}{l}\text { Primorye } \\
\text { and Iturup } \\
\text { Island }\end{array}$ \\
\hline Mean salinity $(\% 0)$ & 34 & 4 & 4-6 & 34 \\
\hline Depth (m) & $0.4-0.5$ & $0.4-0.5$ & $0.3-0.4$ & $0.5-0.6$ \\
\hline Modal particle size (mm) & $0.4-0.8$ & $0.3-0.6$ & $0.3-0.6$ & - \\
\hline $\begin{array}{l}\text { Aleuropelite weight } \\
\text { fraction }(\%)\end{array}$ & 15.8 & 25.8 & 21.2 & - \\
\hline \multicolumn{5}{|l|}{ Harpacticoida species } \\
\hline Nitocra spinipes & 0 & 15 & 32 & 0 \\
\hline Nitocra lacustris & 0 & 23 & 0 & 0 \\
\hline Arenopontia ishikariana & 0 & 0 & 1 & 0 \\
\hline Arenosetella bidenta & 5 & 0 & 0 & 0 \\
\hline Mesochra rapiens & 0 & 7 & 0 & 0 \\
\hline Itunella arenaria & 0 & 0 & 5 & 0 \\
\hline Leimia vaga & 3 & 0 & 0 & 0 \\
\hline Halectinosoma perforatum & 4 & 0 & 0 & 0 \\
\hline Halectinosoma sp. n.1 & 0 & 4 & 0 & 4 \\
\hline Halectinosoma sp. n. 2 & 7 & 19 & 0 & 0 \\
\hline Halectinosoma sp. n. 3 & 19 & 0 & 0 & 0 \\
\hline Harpacticus uniremis & 0 & 0 & 0 & 4 \\
\hline Zaus spinatus & 0 & 0 & 0 & 2 \\
\hline Laophonte inornata & 2 & 0 & 0 & 0 \\
\hline Heterolaophonte discophora & 1 & 0 & 0 & 2 \\
\hline Heterolaophonte hamondi & 0 & 0 & 0 & 1 \\
\hline Paralaophonte perplexa & 0 & 0 & 0 & 1 \\
\hline $\begin{array}{l}\text { Pseudonychocamptus } \\
\text { sp. n. } 1\end{array}$ & 2 & 0 & 0 & 0 \\
\hline Leptastacus japonicus & 5 & 0 & 0 & 0 \\
\hline Paraleptastacus unisetosus & 4 & 0 & 0 & 0 \\
\hline Amphiascoides dimorphus & 0 & 0 & 0 & 5 \\
\hline Amphiascoides sp. n. 1 & 5 & 0 & 0 & 0 \\
\hline Amonardia magna & 0 & 0 & 0 & 3 \\
\hline Diosaccus ezoensis & 0 & 0 & 0 & 2 \\
\hline Paramphiascella curtiseta & 0 & 5 & 0 & 0 \\
\hline Sarsamphiascus minutus & 4 & 0 & 0 & 0 \\
\hline Remanea naksanensis & 0 & 0 & 61 & 0 \\
\hline Parastenhelia spinosa & 3 & 0 & 0 & 0 \\
\hline Parastenhelia sp. n. 1 & 36 & 3 & 1 & 0 \\
\hline Neotachidius parvus & 0 & 24 & 0 & 0 \\
\hline Tisbe furcata & 0 & 0 & 0 & 76 \\
\hline Number of species: & 14 & 8 & 5 & 10 \\
\hline
\end{tabular}


this complex (68\% total abundance). The third was widespread in the upper sublittoral of Kunashir Island, with Nitocra and Halectinosoma representatives of this complex $(70 \%$ of total).

Washed sand taxocenes were localized in distribution and found only in the Primorye region. These taxocenes were dominated by Arenosetella bidenta, Leptastacus japonicus and Paramesochra sp. 1 (>80\% of total abundance). No obligate interstitial species were detected in other investigated areas.

\section{B. Estuaries and brackish-water lagoons}

We describe four main taxocenes in estuarine and brackish-water lagoon environments. Two of these (nos. 2 and 3) were more widely distributed among brackish waters (Table 3). The first (no. 2) including Nitocra lacustris, N. spinipes, Halectinosoma sp. n. 2, and Neotachidius parvus (70-90\% of total) unites estuaries and lagoons (4\%o salinity) from Sakhalin Island and the Primorye region. The similarity of faunal composition of stations from different loci was medium $(\mathrm{D}=0.52 \pm 0.07$ ). The second (no. 3) was characterized by the prevalence of Remanea naksanensis and Nitocra spinipes (80-90\% of total), typical of brackish water (4-6\% salinity) at the Kuril Islands and Primorye region. The type habitat for Remanea naksanensis in South Korea is a brackish water habitat near Naksan beach (Back et al. 2011). The remaining two taxocenes had localized distributions. One in which the dominant genus was Geeopsis (64\% of total abundance) was typical of cold estuaries experiencing about $4 \%$ salinity in the Khabarovsk region; the other, dominated by Leimia and Microarthridion ( $79 \%$ of total), occurred in brackish ( $2 \% 0$ salinity) estuarine bays in the Primorye region.

\section{Macrophyte zone}

Two coastal taxocenes were found in the macrophyte zone in the Kuril Islands and the Primorye region. Tisbe furcata (70-80\% of total) was dominant (Table 3 ) in the most widely distributed of these (no. 4). The similarity of stations from different loci was high $(\mathrm{D}=0.72 \pm 0.06)$. The second, dominated by Diosaccus, Dactylopusia and Harpacticus (60-70\% of total), occurred only in the upper sublittoral of Iturup Island. Literature revealed different phytal communities in the warm waters of the southern part of the East Sea near the Korean Peninsula, with harpacticoids like Porcellidium and Scutellidium longicauda acheloides being prevalent (Song et al. 2010).

Harpacticus, Tisbe, Diosaccus and Dactylopusia were abundant in the phytal zone (50-90\% total harpacticoid abundance in plankton from above the macrophyte zone). Phytal species also constituted about $70 \%$ of harpacticoid taxa identified in stomach contents of Oncorhynchus (salmon) fry.

\section{Comparative biogeographical analysis}

Distribution of ecological groups

Our novel data were obtained from that region encompassing the northern part of the East Sea (mainly the Primorye region; 88 species), and southern part of Okhotsk Sea (coast of Sakhalin and South Kurils; 104 species). Taxonomic inventories from the 
Table 4. Relative abundances of common species and similarity (Kulczynski index) between ecological groups of the different life forms from neighbouring and distant regions of the East Sea and the Sea of Okhotsk.

\begin{tabular}{lcc}
\hline Ecological group & $\begin{array}{c}\text { Neighbouring regions } \\
\left(\text { difference in latitude }<2^{\circ}\right)\end{array}$ & $\begin{array}{c}\text { Distant regions } \\
\left(\text { difference in latitude }>5^{\circ}\right)\end{array}$ \\
\cline { 2 - 3 } $\begin{array}{c}\text { Northern East Sea and } \\
\text { Southern Sea of Okhotsk }\end{array}$ & $\begin{array}{c}\text { North regions and Southern } \\
\text { East Sea (South Korea) }\end{array}$ \\
\hline $\begin{array}{l}\text { Proportion of common species (\%) in faunas } \\
\text { Benthic }\end{array}$ & 21 & $8 \pm 0.46$ \\
Phytal & 29 & $17 \pm 2.8$ \\
Brackish water & 55 & $32 \pm 2.1$ \\
Similarity between faunas (Kulczynski Index) \\
Benthic \\
$\begin{array}{l}\text { Phytal } \\
\text { Brackish water }\end{array}$ & $0.14 \pm 0.08$ & \\
\hline
\end{tabular}

southern part of the East Sea (Korean Peninsula region; 96 species) were obtained from literature sources.

In general, the benthic harpacticoid fauna was highly specific to particular regions. Some common species from one area have a low occurrence even in a neighbouring region (i.e. the southern part of the Sea of Okhotsk and the northern part of the East Sea). The number of common species decreased with increasing distance between regions, and latitude (Table 4). The similarity in the benthic harpacticoid species lists, calculated using the Kulczynski index $(K)$, did not exceed 0.15.

The number of phytal zone species common to neighbouring regions was greater than benthic species, though this decreased with increasing distance between regions being compared (Table 4). The similarities in phytal species lists were also two times greater than those of benthic lists.

The brackish-water fauna proved to be the most cosmopolitan in distribution (Table 4). The number of common species was high for neighbouring and distant regions, with the average similarity in faunal lists from different regions being 0.51 . Thus, the brackish-water species group was the most interzonal and has similar features in the wide latitudinal range.

\section{Latitudinal trends in harpacticoid faunal structure}

We performed a comparative analysis of taxonomic structure of faunas inhabiting different regions of the East and Okhotsk Seas, Yellow and South China Seas, and the southern part of Bering Sea, using our data and that sourced from the literature (Chertoprud et al. 2010; Supplement). Data span a latitudinal range of $2-56^{\circ} \mathrm{N}$, and surface water temperatures of $1-26^{\circ} \mathrm{C}$ (Figure 1).

Comparative analysis of species lists revealed four faunal groups occupying different thermal regimes (Figure 2):

(1) Cold water fauna inhabiting the northern part of Okhotsk and Bering Seas (Commander and North Kuril Islands) as well as the somewhat different 
Bering Sea

Commander Isl.).
South China Sea



Temperature zone (average temperature of the surface water)

$\Delta$ Hot $\left(20-28^{\circ} \mathrm{C}\right)$

$\nabla$ Warm $\left(9-16^{\circ} \mathrm{C}\right)$

Temperate $\left(2-4^{\circ} \mathrm{C}\right)$

Cold $\left(<2{ }^{\circ} \mathrm{C}\right)$

Figure 2. Two-dimensional scaling (MDS) ordination with superimposed clusters of the faunas from different marine areas, based on Kulszinski similarities (stress $=0.14$ ) and factored with the annual surface water temperature.

fauna of the north-western part of the East Sea (Primorye region). This fauna occupied the area of the coldest waters and showed significant similarities with the boreal fauna.

(2) Boreal fauna of the southern Sea of Okhotsk (southern Sakhalin and South Kuril Islands) and north-eastern part of the East Sea (Hokkaido Island).

(3) Warm water fauna of the southern East Sea (Korea Peninsula and southern Japan (Honshu and Kyushu)) and Yellow Sea.

(4) South China Sea tropical fauna.

Faunas of geographically separated areas experiencing similar water temperature characteristics are more similar to each other than they are to some areas at comparable latitude which experience different temperature regimes. For example, the fauna of the southern Sea of Okhotsk was similar to the fauna of Hokkaido Island (northeastern East Sea), both experiencing similar water temperatures, yet the fauna of the Primorye region (north-western East Sea) differed demonstrably.

\section{Discussion}

\section{Characteristic aspects of the regional harpacticoid fauna}

Eighty-eight harpacticoid species were found in the northern part of the East Sea, and 104 species were found in the southern Sea of Okhotsk. A similar number of species has been found in some Arctic seas of comparable area, i.e. the Kara Sea (83 species, Garlitska, pers. comm.) or the Bering and Chukchi Seas (110 species, Chertoprud et al. 2010). Other boreal areas, however, are richer, such as the Black or Mediterranean Seas (239 and 652 species respectively). The species lists remain incomplete for the regions explored (East Sea and Sea of Okhotsk), and further 
studies will likely increase the number of taxa known from each region. The fauna of the northern East Sea has been investigated less than the southern Sea of Okhotsk.

The taxonomic structure of faunas in far eastern seas is relatively typical for boreal regions. The highest species richness was in five families: Miraciidae (21), Ectinosomatidae (15), Laophontidae (13), Ameiridae (12), and Thalestridae (12 species). The first four of these families are typical of soft sediment environments, whereas the last is specific to the phytal zone. The highest species richness is found in the epibenthic genus Halectinosoma (nine species) and in the four phytal genera Dactylopusia (five), Harpacticus (five), Scutellidium (six) and Tisbe (six).

The phytal complex includes a few species-rich genera, whereas the benthic fauna is more genus-rich. Species from the typically warm-water family Porcellidiidae are absent in the northern part of the East Sea and the Sea of Okhotsk and occur only in the southern part of the East Sea. Two families (Longipedidae and Canuellidae) were represented by single species each, despite their usually high abundance in subtropical and temperate latitudes. This observation could be a consequence of some biogeographic peculiarity of the region or an artefact of under-investigation. Further studies in this region are required to more fully address this question.

The composition of the harpacticoid life forms reflected the diversity of studied habitat types. The diversity of interstitial species in all regions is low. Even for regions in which the fauna is relatively well-studied, small obligate interstitial forms are usually underestimated because of limitations in sampling techniques (Chertoprud and Garlitska 2007). Further research will likely increase the number of species in this ecological group. Only two plankton species (both Microsetella) were found, though such low richness is typical of boreal latitudes (Lang 1948).

About one-third (24-32\%) of harpacticoids found in the northern part of the East Sea and southern part of Sea of Okhotsk had boreal distribution ranges that corresponded to the latitudinal range of investigated seas. Another third of species are 'provisional endemics,' restricted to one of the studied areas, not having been reported elsewhere.

Our knowledge of harpacticoids of the western Pacific is imperfect, and distribution ranges of many species are not fully documented or understood. Accordingly, the number of endemic taxa may decrease considerably in the future. For example, the present study extended the ranges of Ameira zahaae, Itunella arenaria and Remanea naksanensis, all previously known only from type localities in the southern part of the East Sea and Yellow Sea (Lee and Chang 2008; Back et al. 2011; Karanovic and Cho 2012). These three species were found in the Primorye region and South Kuril Islands. Cosmopolitan species comprised $10-13 \%$ of the total number of species detected, of which about half (five species) were brackish-water members of the genera Nitocra, Nannopus, Mesochra and Onychocamptus. However, the taxonomic status and wide distribution of many estuarine harpacticoids remains the subject of debate (Garlitska et al. 2012; Chertoprud et al. 2014).

\section{Main factors determining the diversity of taxocenes inhibiting different habitats}

\section{A. Soft bottom communities}

The composition of benthic harpacticoid taxocenes is determined primarily by sediment type (Chertoprud et al. 2006). The intensity of harpacticoid reproduction 
(Chertoprud and Azovsky 2005) and impact of predation (Coull 1985) are related to substratum type. The composition of the life forms in a community is mainly determined by sediment type (Hicks and Coull 1983). Our data clearly distinguished two taxocene complexes: the first typical of silty sand with detritus and the second of washed sand. Relatively large epibenthic forms dominated the first substratum, and small worm-like or flattened interstitial species, the second. According to our data, if muddy bays alternate with sandy beaches along the coast, the distribution of taxocenes would follow the pattern of sediments.

Similar but spatially distant habitats may differ in species composition. Such patchiness may not only be a result of environmental heterogeneity, but reflect the probabilistic nature of colonization events (Chertoprud et al. 2006). Often the speed and success of settlement in new territories is a deciding factor for biotope colonization of one or other harpacticoid species. As a result, relatively stable taxocenes are formed at different loci, and the coadaptation of these species contributes to the resilience of the system against the introduction of 'foreign' elements (Thorson 1958).

\section{B. Estuarine and lagoon communities}

Salinity in water bodies ranged 2-8\%o. Reduced salinity usually limits the basic set of dominant taxa and the species richness (Van Damme et al. 1984; Moore 1987). Indeed, according to our data, the number of species varied from 5 to 8 in the most common brackish-water taxocenes, whereas the number in marine communities always exceeded 10 (Table 3). The interzonal nature of estuarine harpacticoid fauna has been hypothesized recently (Chertoprud et al. 2013). It was shown that the similar generic composition of brackish-water assemblages was typical over a wide-latitudinal range from the Arctic to the tropics. About half of the species recorded from the Arctic to the tropics are common in the estuaries of southern India, the White Sea and the Russian Far East (Chertoprud et al. 2014). In this study, predominant brackish-water genera (Nitocra, Halectinosoma, Geeopsis and Microarthridion) were distributed across a wide latitudinal range. Other genera were more restricted in distribution, including brackish representatives like Leimia (L. vaga), Huntemannia (H. biarticulatus), Remanea ( $R$. naksanensis) and Neotachidius ( $N$. parvus). These species also reached a large population size, but were not endemics.

There was no immediately apparent relationship between taxocene composition and salinity gradient. For example, a salinity of $4 \%$ is preferred by inhabitants of three of the four allocated taxocenes with the following dominant representatives: Nitocra lacustris, N. spinipes, Halectinosoma sp. n. 2, Huntemannia biarticulatus and Neotachidius parvus; Remanea naksanensis and Nitocra spinipes; and Geeopsis incisipes. We did not find any clear across-estuary changes in fauna, possibly because of weak salinity gradients and the limited number of stations studied. It is clear that one of the determinants of dominance in the estuarine community is sediment type. Thus, the predominance of the obligate interstitial Remanea naksanensis is typical for coarse washed sand in brackish water areas. Additionally, climate has a significant influence on the formation of species complexes. For example, the subarctic genus Geeopsis dominated the northernmost Tumnin estuary (Khabarovsk district), but was not found in the more southerly regions. Colonization abilities of species probably play a role in some other cases. 


\section{Phytal zone communities}

Macroalgal-associated harpacticoids often have common morphological adaptations, such as flattened (Alteutha, Zaus) or pear-shaped (Diosaccus) bodies; or extensive thoracic segments in combination with a narrow abdomen (Tisbe) (Hicks and Coull 1983). Species with these attributes were abundant in the macrophyte community and formed the basis of taxocenes. As noted previously, the composition of harpacticoid faunas differed not only in respect to algae of different taxonomic groups, but also in relation to different parts of a single macrophyte (Chislenko 1968; De Troch et al. 2001). Thus, clear differences can be traced between the copepod groups inhabiting coastal thickets and Syringodium and Halophila algae (De Troch et al. 2001); as well as the thallus surface, the rhizoid Laminaria (Chislenko 1968), and the leaves and rhizoids of Thalassia (De Troch et al. 2001).

Algal shape and biotope differentiation of the phytal zone are key factors determining the structure of harpacticoid assemblages. The first phytal taxocene with the prevalence of Tisbe was found in a complex dominated by brown algae (Fucus). The second taxocene with Diosaccus, Dactylopusia and Harpacticus predominant, was found on Zostera sp. We investigated the entire fauna of the plants without separating the different morphological fragments. The first taxocene is typical of macrophytes growing in closed and slightly brackish (22\%) bays. Another taxocene was found in bays with a high rate of water exchange, surf, and almost marine salinity $(28-30 \%$ ). Thus, both abiotic and biotic factors that regulated formation of the harpacticoid species complexes in the phytal zone interacted.

Harpacticoids are a common prey type for different species of fish fry (Borutzky 1960; Ivankov et al. 1999). According to our preliminary data, only taxa associated with phytal forms are common in salmon fry diet. This is probably because the fry feed between macrophytes where phytal species are actively entering the water mass (Thistle 2003; Giere 2009). The copepod composition in plankton samples from coastal waters confirms this hypothesis. Indeed, there is evidence that juvenile fish preferentially eat the fauna of dense substrates (phytal and clay sediments) where organisms cannot hide between sediments particles (Coull 1985). The evaluation of the different ecological harpacticoid group contributions to fish nutrition requires further investigation.

\section{Distribution of ecological groups: the paradox of brackish-water fauna}

Comparative analysis of the distribution of the three main ecological groups (marine benthic fauna, fauna of the phytal zone, and brackish-water fauna) showed benthic species to be locally distributed, estuarine species to have the widest distributions, and phytal species to have distributions of somewhat transitional extent. Obviously, the composition of life forms in different species complexes varies significantly. Epibenthic and interstitial forms predominate in marine soft sediments, while phytal forms predominate on macrophytes, and epibenthic species are most abundant in the brackish estuarine fauna. As we have shown previously, planktonic harpacticoids have the greatest distributional range, followed by phytal and epibenthic forms, while interstitial species have the most restricted ranges (Chertoprud et al. 2010). These differences are mainly determined by the dispersal ability of harpacticoids and correlate with habitat mobility (e.g. water masses and floating algae versus sediments) 
and species leg morphology (Bell et al. 1987; Thistle and Sedlacek 2004). Small interstitial species have lanceolate or vermiform bodies with short legs and are closely associated with certain types of sediments, often avoiding horizontal transfer through water drift by burrowing deeper into the sediment during high tides (Rybnikov et al. 2003). Epibenthic species have relatively well-developed swimming legs, but usually they are clearly linked to their life cycles in a bottom substrate and are rarely abundant in the water column (Hicks and Coull 1983). Epibenthic species are usually transferred by coastal currents over small distances of 10-100 km (Hauspie and Polk 1973). Accordingly, phytal fauna can colonize distant habitats faster than interstitial or epibenthic faunas can. Many phytal species enter the water column and are carried by currents; those representatives that are otherwise strongly fixed on algae can be transferred with dislodged macrophyte fractions (Kurdziel and Bell 1992; Ólafsson et al. 2001). The high colonization ability of phytal species is reflected in the high proportion $(31 \%)$ of species with transatlantic distribution ranges among them (Chertoprud et al. 2010).

It is paradoxical that brackish-water species are primarily epibenthic taxa with extensive distributions. It seems that the distribution of this ecological group should be similar to that of benthic taxa, or even narrower because of the fragmentation of estuarine habitats. However, in areas separated by more than $1000 \mathrm{~km}$ (the northern and the southern parts of the East Sea), over 30\% of species are common to all brackish-water loci, whereas this figure for marine benthic species is less than $10 \%$. In Russian Far East waters, 40\% of brackish-water harpacticoid species and only 13\% of marine harpacticoids are cosmopolitan (Chertoprud et al. 2014). Many widespread estuarine species actually constitute complexes of cryptic species with similar morphology, but which differ genetically (Garlitska et al. 2012). A prerequisite for this is the geographic dispersion of estuaries with rather broad maritime areas, leading to reproductive isolation of local species. In addition, environmental conditions in the estuaries of different latitudes vary considerably, which can also lead to speciation. Molecular analyses of individuals from different brackish-water species, such as Nannopus palustris (Garlitska et al. 2012), Microarthridion littorale (Schizas et al. 1999) and Cletocamptus deitersi (Rocha-Olivares et al. 2001) revealed that these three species are actually groups of cryptic taxa.

\section{Latitude-dependent variability of faunas of the East Sea and southern part of Sea of Okhotsk}

The area throughout which our study is focussed is characterized by a distinct latitudinal water temperature gradient, with an average annual surface temperature of $2-16^{\circ} \mathrm{C}$ (Japan Meteorological Agency 1991), attributable to numerous warm and cold currents throughout the region (Shuntov 2001). For example, the southern part of the East Sea is influenced by the Tsushima and East Korean warm currents. The intensity of these flows decreases gradually towards the northern part of the East Sea. A branch of the Tsushima Current named the Soya penetrates through the straits in the southern part of the Sea of Okhotsk, bringing with it warm water to the southern Sakhalin and the Kuril Islands. Cold currents coming from north of the East Sea affect Primorsky, Schrenk, and North Korea.

The harpacticoid faunas investigated in the East Sea and the southern part of the Sea of Okhotsk corresponded to three temperature regions (Figure 1) allocated 
according to Japan Meteorology Agency data (1991), based on the long-term average annual isotherms of the surface water masses:

(1) The southern part of the East Sea: the coast of Korea, the Kyushu and Honshu Islands bounded in the south by a $16^{\circ} \mathrm{C}$ isotherm, and in the north by a $9^{\circ} \mathrm{C}$ isotherm. This area is characterized by relatively warm water masses throughout the year.

(2) The north-western part of the East Sea: coast of Primorye and Khabarovsky regions of Russia bounded on the south by a $2{ }^{\circ} \mathrm{C}$ isotherm, in which the sea always partially freezes during winter (for 3-4 months per year).

(3) The north-eastern part of the East Sea and the southern part of the Sea of Okhotsk: coast of Hokkaido, southern Sakhalin, and the South Kuril Islands bounded on the south by a $4^{\circ} \mathrm{C}$ isotherm, and in the north by a $2^{\circ} \mathrm{C}$ isotherm. The sea only freezes near the northern coasts of Hokkaido and South Kuril Islands for approximately two months of each year.

The taxonomic structure of harpacticoid species complexes inhabiting these three regions (north-western part of the East Sea; the north-eastern East Sea and the southern part of the Sea of Okhotsk; and the southern East Sea) differ significantly. The Kulczynski similarity index $(K)$ value was not more than $0.39 \pm 0.1$. Not more than $50 \%$ of the common species were included in the lists for the three temperature regions. The biogeographical structure of the fauna of the three species complexes was also different (Figure 3).

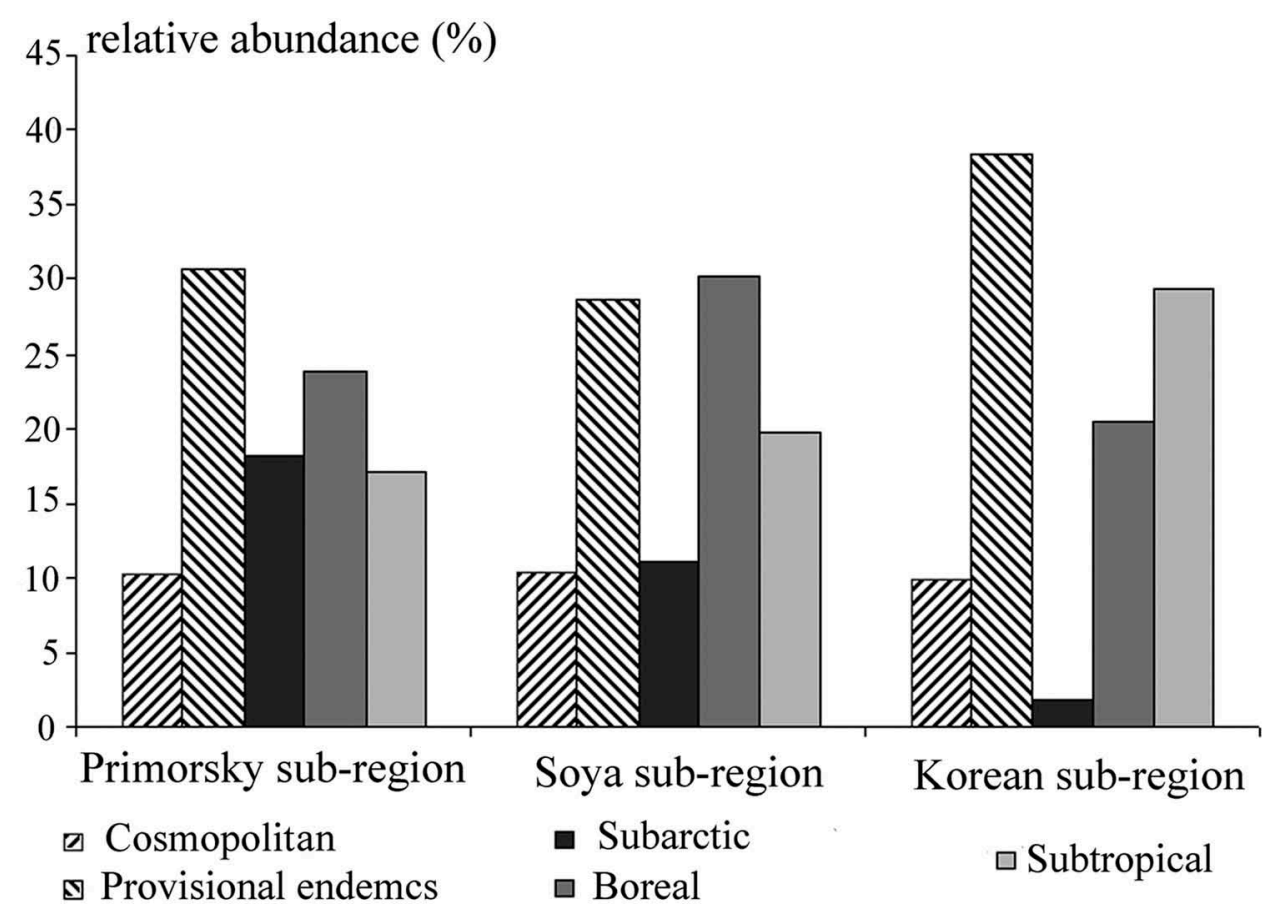

Figure 3. Biogeographical structure of the faunas from the three main species complexes in the East Sea and the southern part of the Sea of Okhotsk. Relative species abundances with different distribution ranges are presented. 
The diversity of species with widespread boreal and subarctic distribution was higher in the northern regions (41-42\% of total fauna), and low in the southern part of the East Sea $(22 \%)$. In contrast, species with tropical and subtropical distribution are highly diverse near the Korean Peninsula (29.5\%). The number of subtropical species near Hokkaido and the Kuril Islands was slightly higher than that in the Primorye region: $20 \%$ and $17 \%$, respectively. The fauna of the southern part of the Sea of Okhotsk was closer to the fauna of the southern waters of the East Sea $(K=0.44 \pm 0.09)$ than to the fauna of the north-western part of the East Sea $(K=0.28 \pm 0.09)$. The effects of currents on the distribution of copepod fauna has been noted before (Hauspie and Polk 1973). Tropical species prevail in the northern Yellow Sea and South China Sea where they are strongly influenced by the Kuroshio warm current. A transitional area was located between $29^{\circ}$ and $32^{\circ} \mathrm{N}$ and west of $123^{\circ} \mathrm{E}$ in the East China Sea where the warm-temperate and tropical faunas mix (Chen et al. 1982).

The environment within the East Sea and the southern part of the Sea of Okhotsk is highly variable, and within it at least three relatively isolated complexes of harpacticoids occur within areas subject to different average annual surface water temperature:

(1) The Korean sub-region, situated on the southern and south-western East Sea, under influence of Tsushima and East Korea warm currents (average annual surface water temperature $9-16^{\circ} \mathrm{C}$ ), with a total species count of 112 . Provisional endemics comprised $<40 \%$ of the total fauna, which otherwise included many tropical taxa, with a low percentage of boreal species (Figure 3).

(2) The Primorye sub-region, characterized by a boreal climate in the northwestern part of the East Sea, where the Primorsky Current is the main influencing factor (average annual surface water temperature not more than $2^{\circ} \mathrm{C}$ ). In total 88 species were recognized within this region; provisional endemics comprised a third of this number, with boreal and typical arctic species dominating the fauna, in which tropical taxa were rare (Figure 3).

(3) The Soya sub-region, including the north-eastern coasts of Hokkaido and South Kuril Islands, with boreal climate influenced by the Soya warm current (with an average annual surface water temperature of $2-4^{\circ} \mathrm{C}$ ). Here 126 species were recorded, with the proportion of provisional endemics being slightly lower than a third of this number. A mix of boreal and tropical faunal elements occurred in this area (Figure 3). This fauna has features transitional to those of Korea and Primorye sub-regions.

Subdivision of the East Sea and Sea of Okhotsk into meiobenthic sub-regions is undertaken for the first time. Similar schemes of zonation for this sector of the Pacific Ocean have been presented for zooplankton, macrobenthos, and ichthyofauna (Kuhn 1975; Kafanov et al. 2000; Golikov et al. 2001). The southern part of the East Sea is diverse with tropical and subtropical zooplanktonic species that are absent in northern parts of the area (Kuhn 1975). Subtropical and boreal zooplankton species cooccur here, the former preferring surface waters, the latter the deeper layers (Nishimura 1969). On the basis of distributions of shell-bearing gastropods Golikov et al. (2001) subdivided this area into four sub-regions, distinguishing the north- 
western part of the East Sea (with psychrophilic fauna) from the South Kuril Islands (Kunashir and Iturup), an area occupied by thermophilous gastropods. Kafanov et al. (2000), using the data on the East Sea fishes, distinguished as many as 10 biogeographic provinces in this region. The complexes of southern, north-western, and north-eastern parts of the region are different; the tropical and subtropical species mark north-eastern provinces but are absent from north-western provinces.

There is obvious biogeographic heterogeneity in the faunas of the Far East region. Further studies are needed to clarify the proposed zonation of waters of the East Sea and the Sea of Okhotsk for marine harpacticoids, and to extend the biogeographical scheme on the meiobenthic community as a whole.

\section{Conclusion}

Our analysis based on original and published data for harpacticoid faunas from the areas investigated in the Far East contributes the following ecological observations:

(1) The total species inventory of Harpacticoida from the northern part of the East Sea comprises 88 species; 104 species have been reported from the southern part of the Sea of Okhotsk. As a result of our study, the number of species known from the first region has increased by more than three times, and by more than 10 times for the second.

(2) Twelve harpacticoid species complexes can be distinguished: six taxocenes in soft sediments, two inhabiting the phytal zone, and four characteristic of estuaries and brackish lagoons in the northern part of the East Sea and the southern part of the Okhotsk Sea.

(3) The marine benthic (epibenthic and interstitial) harpacticoid fauna showed maximum regional specificity, whereas the brackish-water fauna was the most cosmopolitan; the phytal zone fauna had intermediate values.

(4) The East Sea is highly variable environmentally by virtue of its geographical location and hydrological regime. At least three discrete harpacticoid copepod assemblages exist within it. Further analyses of meiobenthic community structure in the Far East sector will improve our knowledge of observed patterns.

\section{Disclosure statement}

No potential conflict of interest was reported by the authors.

\section{Funding}

This study supported by the Russian Foundation for Basic Research [project nos. 13-04-00148 and 15-04-02245], and partially by the Deep Sea Environmental Study in North East Pacific [PM57953 and PM57954] of KIOST.

\section{Supplemental material}

Supplemental material for this article can be accessed here: [http://dx.doi.org/10.1080/ 00222933.2015.1056268] 


\section{ORCID}

Wonchoel Lee (1) http://orcid.org/0000-0002-9873-1033

\section{References}

Azeria ET. 2004. Terrestrial bird community patterns on the coralline islands of the Dahlak Archipelago, Red Sea, Eritrea. Glob Ecol Biogeogr. 13:177-187.

Azovsky AI, Garlitska LA, Chertoprud ES. 2012. Broad-scale patterns in local diversity of marine benthic harpacticoids (Crustacea). Mar Ecol Prog Ser. 460:63-77.

Back J, Lee W, Huys R. 2011. A new species of Remanea Klie, 1929 (Copepoda: Harpacticoida: Paramesochridae) with a redescription of the type species. J Nat Hist. 45:2939-2964.

Back J, Lee W. 2012. Two new species of Apodopsyllus (Copepoda, Harpacticoida) from Jeju Island, Korea. Zootaxa. 3368:128-145.

Back J, Lee W. 2013. Three new species of the genus Paramesochra T. Scott, 1892 (Copepoda: Harpacticoida: Paramesochridae) from Yellow Sea, Korea with a redescription of Paramesochra similis Kunz, 1936. J Nat Hist. 47:769-803.

Bell SS, Walters K, Hall MO. 1987. Habitat utilization by harpacticoid copepods: a morphometric approach. Mar Ecol Prog Ser. 35:59-64.

Bodin P. 1997. Catalogue of the new marine Harpacticoid Copepods (1997 Edition). Documents de Travail de l'Institut Royal des Sciences Naturelles de Belgique. 89:1-304.

Borutzky EW. 1929. Enhydrosoma uniarticulatum sp. n. (Copepoda Harpacticoida) ein neuer Vertreter der Gattung Enhydrosoma. Zool Anz. 80:158-160.

Borutzky EV. 1960. Key of free-living freshwater copepods of the USSR and adjacent countries on the basis of fragments in the intestines of fishes. Moscow: Academy of Sciences of the USSR. Russian.

Boxshall GA, Halsey SH. 2004. An introduction to copepod diversity. London: The Ray Society.

Carman KR, Fleeger JW, Pomarico SM. 1997. Response of a benthic food web to hydrocarbon contamination. Limnol Oceanogr. 42:561-571.

Chen Q, Chen Y, Hu Y. 1982. A study of the plankton communities in the South Yellow Sea and the East China Sea. Hai Yang Xue Bao. 1:259-266. Chinese.

Chertoprud ES. 2013. Check-List of species of free-living invertebrates of the Russian Far Eastern Seas. In: Sirenko BI, editor. Order Harpacticoida. St. Petersburg: Zoological Institute of RAS; p. 88-91.

Chertoprud ES, Azovsky AI. 2005. Seasonal dynamics of intertidal harpacticoids (Harpacticoida: Copepoda) on the White Sea. Oceanology. 46:71-80.

Chertoprud ES, Chertoprud MV, Kondar DV, Kornev PN, Udalov AA. 2006. Harpacticoida taxocen diversity in the silt-sand intertidal zone of Kandalaksha Bay of the White Sea. Oceanology. 46:492-500.

Chertoprud ES, Frenkel SE, Novichkova AA, Vodop'yanov SS. 2014. Harpacticoida (Copepoda) fauna and the taxocenes structure of brackish lagoons and estuaries of the Russian Far East. Oceanology. 54:739-751.

Chertoprud ES, Garlitska LA. 2007. A comparative analysis of the Harpacticoida (Copepoda) faunas from the northern and southern seas of Russia. Oceanology. 47:51-59.

Chertoprud ES, Garlitska LA, Azovsky AI. 2010. Large-scale patterns in marine benthic harpacticoid diversity and distribution. Mar Biodiv. 40:301-315.

Chertoprud ES, Gheerardyn H, Gómez S. 2013. Community structure of harpacticoid copepods in intertidal and shallow-water habitats of Cat Ba archipelago (Vietnam, South China Sea). J Mar Biol Assoc UK. 93:95-105. 
Chislenko LL. 1968. Nomogram for determining the weight of aquatic organisms on the basis of size and shape of the body. Leningrad: Nauka. Russian.

Chislenko LL. 1971. New common forms of harpacticids (Copepoda, Harpacticoida) from Possjet Bay of the Sea of Japan. Issledovaniya Fauny Morei. 8:151-181. Russian.

Chislenko LL. 1978. New species of harpacticoids copepods (Copepoda, Harpacticoida) from the Possjet bay, Sea of Japan. Tr Zool Inst. 61:161-192.

Chislenko LL. 1980. Three new harpacticoid species (Copepoda, Harpacticoida) from the Kurile Islands. Issledovaniya Fauny Morei. 25:77-88.

Chupachin VM, Kaev AM. 1980. Distribution and some features of biology of pink salmon and chum juveniles at the shelf of Iturup Island. Izv TINRO. 104:116-121. Russian.

Clarke KR, Gorley RN. 2001. Primer, user manual/tutorial. v5 ed. Plymouth: PRIMER-E Ltd.

Costello MJ, Emblow C, White R. 2001. European register of marine species: A check-list of marine species in Europe and a bibliography of guides to their identification. Patrimoines Naturels. 50:1-463.

Coull BC. 1985. The use of long-term biological data to generate testable hypotheses. Estuaries. 8:84-92.

De Troch M, Fiers F, Vincx M. 2001. Alpha and beta diversity of harpacticoid copepods in a tropical seagrass bed: the relation between diversity and species' range size distribution. Mar Ecol Prog Ser. 215:225-236.

Fadeeva NP. 1991. Distribution of free-living nematodes in the Kievka Bay area. In: Biological studies of benthos and epibioses in the Sea of Japan. Vladivostok: Far Eastern Branch of the USSR Academy of Sciences; p. 66-84. Russian.

Fadeeva NP, Belogurov OI. 1984. The morphology of four species of the genus Sabatieria (Nematoda, Comesomatidae) from the Sea of Japan. In: Hydrobiological studies of bays and coves from Primorye. Vladivostok: Far Eastern Branch of the USSR Academy of Sciences; p. 81-96.

Finlay BJ, Fenchel T. 2004. Cosmopolitan metapopulation of free-living microbial eucariotes. Protist. 155:237-244.

Garlitska L, Neretina T, Schepetov D, Mugue N, De Troch M, Baguley JG, Azovsky A. 2012. Cryptic diversity of the 'cosmopolitan' harpacticoid copepod Nannopus palustris: genetic and morphological evidence. Molec Biol. 21:5336-5347.

Giere O. 2009. Meiobenthology. The microscopic motile fauna of aquatic sediments. 2nd ed. Berlin: Springer.

Golikov AN, Sirenko BI, Gulbin VV, Chaban EM. 2001. Checklist of shell-bearing gastropods of the northwestern Pacific. Ruthenica. 11:153-174.

Gur'ianova EF. 1964. Zoogeographical zoning of the benthic fauna of the World Ocean (benthic fauna of the continental shelf). Physiographic Atlas of the World. Moskow: AS USSR. Map 68B. Russian.

Hauspie R, Polk PH. 1973. Swimming behaviour patterns in certain benthic harpacticoids (Copepoda). Crustaceana. 25:95-103.

Hicks GRF, Coull BC. 1983. The ecology of marine meiobenthic harpacticoid copepods. Oceanogr Mar Biol Ann Rev. 21:67-175.

Huys R. 2009. Unresolved cases of type fixiation, synonymy and homonymy in harpacticoid copepod nomenclature (Crustacea: Copepoda). Zootaxa. 2183:1-99.

Itô T. 1968. Descriptions and records of marine harpacticoids copepods from Hokkaido, I. J Fac Sci, Hokkaido Univ Ser VI Zool. 16:369-381.

Itô T. 1969. Descriptions and records of marine harpacticoids copepods from Hokkaido, II. J Fac Sci, Hokkaido Univ Ser VI Zool. 17:58-77.

Itô T. 1970. Descriptions and records of marine harpacticoids copepods from Hokkaido, III. J Fac Sci, Hokkaido Univ Ser VI Zool. 43:211-218.

Itô T. 1972. Description and records of marine harpacticoid copepods from Hokkaido, IV. J Fac Sci, Hokkaido Univ Ser VI Zool. 18:305-336. 
Itô T. 1974. Description and records of marine harpacticoid copepods from Hokkaido, V. J Fac Sci, Hokkaido Univ Ser VI Zool. 19:546-640.

Itô T. 1976. Descriptions and records of marine harpacticoid copepods from Hokkaido, VI. J Fac Sci, Hokkaido Univ Ser VI Zool. 20:448-567.

Itô T. 1979. Descriptions and records of marine harpacticoids copepods from Hokkaido, VII. J Fac Sci, Hokkaido Univ Ser VI Zool. 22:42-68.

Itô T. 1981. Descriptions and records of marine harpacticoids copepods from Hokkaido, VIII. J Fac Sci, Hokkaido Univ Ser VI Zool. 22:422-450.

Ivankov VN, Andreev VV, Tyapkina NV, Ruchlov FN, Fadeeva NP. 1999. Biology and feeding base of juvenile Pacific salmons during the early period of ocean life. Vladivostok: Far Eastern University. Russian.

Japan Meteorological Agency. 1991. Climatic chart of sea surface temperatures of the Western North Pacific and the global ocean. PICES Sci Rep. 1:25-122.

Kaev AM. 2003. Features of reproduction of chum salmon in relation with its size and age population structure. Yuzhno-Sakhalinsk: SahNIRO. Russian.

Kaev AM, Chuhpalin VM, Fedotova NA. 1993. Feeding habits and food relationships of juvenile salmon in coastal waters of Iturup Island. J Ichthyol. 33:215-224.

Kafanov AI, Volvenko IV, Fedorov VV, Pitruk DL. 2000. Ichthyofaunistic biogeography of the Japan (East) Sea. J Biogeogr. 27:915-933.

Karanovic T, Cho JL. 2012. Three new ameirid harpacticoids from Korea and first record of Proameira simplex (Crustacea: Copepoda: Ameiridae). Zootaxa. 3368:91-127.

Kuhn MS. 1975. Zooplankton of the Far Eastern Seas. Moscow: Food Industry. Russian.

Kurdziel JP, Bell SS. 1992. Emergence and dispersal of phytaldwelling meiobenthic copepods. J Exp Mar Biol Ecol. 163:43-64.

Lang K. 1948. Monographie der Harpacticiden, I \& II. Stockholm: Nordiska Bokhandeln.

Lang K. 1965. Copepoda Harpacticoidea from the Californian Pacific coast. Kunglieren svenska Vetenskapsakademiens Handlingar. Stockholm: Nordiska Bokhandeln.

Lee JM, Chang CY. 2008. Two canthocamptid copepods of the genera Itunella and Mesochra (Harpacticoida, Canthocamptidae) from brackish waters in South Korea. J Nat Hist. 42:1729-1747.

Magurran AE. 2004. Measuring biological diversity. Oxford: Blackwell Publishing.

Mirkin BM, Naumova LG, Solomeshch AI. 2001. Present-day plant science. Moscow: Logos. Russian.

Moore CG. 1987. Meiofauna of the industrialised estuary and Firth of Forth, Scotland. Proc Royal Soc Edinburgh. 93:415-430.

Murray KG, Winnett-Murray K, Hertel L. 2002. Species diversity, island biogeography, and the design of nature reserves. Tested Stud Lab Teach. 23:125-143.

Nishimura S. 1969. The zoogeographical aspects of the Japan Sea. Publ. Seto Mar Biol Lab. 17:67-142.

Ólafsson E, Ingólfsson A, Steinarsdóttir MB. 2001. Harpacticoid copepod communities of floating seaweed: controlling factors and implications for dispersal. Hydrobiologia. 453-454:189-200.

Pavluk ON. 1984. New species of free-living nematodes from Sea of Japan and the comments about the genera Halanonchus. Zool Zhurnal. 13:1144-1149.

Pavluk ON, Belogurov OI. 1979. Species of the genus Parodonthophora (Nematoda: Araeolaimida) from Japan and Okhotsk Seas. In: Studies of pelagic and benthic organisms of Far Eastern Seas. Vladivostok: Far Eastern Branch of the USSR Academy of Sciences; p. 66-74.

Pesce GL 2007. Harpacticoida. In Copepod Web Portal; [cited 2004 Apr 30]. Available from: http://www.luciopesce.net/copepods/arpa.htm 
Rocha-Olivares A, Fleeger JW, Foltz DW. 2001. Decoupling of molecular and morphological evolution in deep lineages of a meiobenthic harpacticoid copepod. Molec Biol Evol. 18:1088-1102.

Rybnikov PV, Kondar DV, Azovsky AI. 2003. Properties of the White Sea littoral sediments and their influence on the fauna and distribution of Harpacticoida. Oceanology. 43:91-102.

Schizas NV, Street GT, Coull BC, Chandler GT, Quattro JM. 1999. Molecular population structure of the marine benthic copepod Microarthridion littorale along the southeastern and Gulf coasts of the USA. Mar Biol. 135:399-405.

Shuntov VP. 2001. Biology of the Far Eastern seas of Russia. 1. Vladovostok: TINRO-Center. Russian.

Smirnova EV. 2012. Structure and dynamics of communities of sandy sediments from shallow coastal areas of the northwestern part of the Sea of Japan [dissertation]. Vladivostok: Publishing House of the Far Eastern University. Russian.

Song SJ, Ryu J, Kim JS, Kim W, Yun SG. 2010. Seasonal variability of community structure and breeding activity in marine phytal harpacticoid copepods on Ulva pertusa from Pohang, east coast of Korea. J Sea Res. 63:1-10.

Thistle D. 2003. Harpacticoid copepod emergence at a shelf site in summer and winter: implications for hydrodynamic and mating hypotheses. Mar Ecol Prog Ser. 248:177-185.

Thistle D, Sedlacek L. 2004. Emergent and non-emergent species of harpacticoid copepods can be recognized morphologically. Mar Ecol Prog Ser. 266:195-200.

Thorson G. 1958. Perspectives in marine biology. In: Buzzato-Traverso AA, editor. Parallel level-bottom communities, their temperature adaptation, and their "balance" between predators and food animals. Berkely: University California Press; p. 67-86.

Trofimov IK. 1999. On the nutrition of Pacific herring Clupea pallasi pallasi from Kamchatka lakes Nerpichye and Vilyuy in marine and freshwater life periods. J Ichthyol. 39:375-383.

Urbakh VY. 1975. Statistical Analysis in Biological and Medical Studies. Moskow: Meditsina. Russian.

Van Damme D, Heip C, Willems KA. 1984. Influence of pollution on the harpacticoid copepods of two North Sea estuaries. Hydrobiologia. 112:143-160.

Wells JBJ. 2007. An annotated checklist and keys to Copepoda Harpacticoida (Crustacea). Zootaxa. 1568:1-872.

Willen E. 2002. Notes on the systematic position of the Stenheliinae (Copepoda, Harpacticoida) within the Thalestridimorpha, and description of two new species from Motupore Island, Papua New Guinea. Cah Biol Mar. 43:27-42.

Zavarsin DS, Atamanova IA. 2014. Zooplankton seasonal dynamics in Ptichye Lake and adjoining sea costal waters of southern Sakhalin. Materials of Vladimir Ya. Levanidov Biennial Memorial Meeting. T. 6. Vladivostok: Far Eastern University. Russian.

Zezina ON. 1976. Ecology and Dispersal of Present Brachiopods. Moskow: Nauka. Russian. 